\title{
Strategic State Capacity: \\ How States Counter Opposition to Climate Policy
}

\author{
Jonas Meckling ${ }^{1}$ \\ University of California, Berkeley
}

\author{
Jonas $\mathrm{Nahm}^{2}$ \\ Johns Hopkins University
}

\begin{abstract}
When can states implement policies against the opposition from powerful interest groups? Research on state capacity has centered on bureaucratic sources of capacity, leaving unexplained why countries with similar levels of bureaucratic capacity vary in goal attainment. We introduce the notion of strategic state capacity to explain this puzzle. It refers to the ability of the state to mobilize or de-mobilize interest groups in pursuit of policy goals. We identify four general types of strategies states use to counter opposition: recruiting allies, aligning interests, limiting access, and quieting interests. We examine these in cases on climate and clean energy policy-making in California, France, Germany, and the United States. Climate politics is an increasingly important field of distributive politics with powerful policy losers. The idea of strategic state capacity complements bureaucratic notions of capacity to show how the state actively organizes its relations with interest groups to advance policy goals.
\end{abstract}

\footnotetext{
${ }^{1}$ Jonas Meckling (meckling@berkeley.edu) is an Associate Professor in the Department of Environmental Science, Policy, and Management at the University of California, Berkeley.

2 Jonas Nahm (jnahm@jhu.edu) is an Assistant Professor in the School of Advanced International Studies at Johns Hopkins University.

This paper was prepared for the annual meeting of the American Political Science Association, September 2020.
} 


\section{Introduction}

Scholars in comparative politics have long examined how states can implement political goals against the opposition from powerful organized interests (Skocpol, 1985). Research on the United States in particular has shown that the state is often weak vis-à-vis organized interests. Business interests tend to prevail against both the state and society (Evans, 1997; Gilens \& Page, 2014; Krasner, 1978; Paster, 2013). The prevalence of regulatory capture has been shown across a number of policy areas, including financial regulation, healthcare policy, and antitrust policy. Regulatory and legislative capture by business elites is also prevalent in climate politics, an increasingly important area of distributive politics (Aklin \& Mildenberger, 2020; Hochstetler \& Kostka, 2015). Despite public support for climate policy in advanced economies, over 25 years of attempts to develop ambitious climate policy against interest group opposition have fallen short of sufficiently reducing greenhouse gas emissions to mitigate climate change (IPCC, 2018). The resounding message of such research is that states frequently fail to implement public goals when they succumb to private interests.

In spite of such challenges, the United States and other advanced industrialized states have at times been surprisingly successful at overcoming fierce opposition from organized interests. Since the interventionist policies of the New Deal, scholars have examined the sources of the US government's strength to intervene in the economy and to prevent capture (Carpenter, 2001; Carpenter \& Moss, 2014; Skocpol \& Finegold, 1982). As the United States and other countries are now engaging with the idea of a Green New Deal, such debates have again gained urgency. In climate policy, some successes in the recent past suggest possibilities for effective state intervention: California, New York, Germany, Denmark, the United Kingdom, but also the US federal government under the Obama administration were able to pass climate policies against the opposition of energy and energy-intensive manufacturing industries and labor unions (Aklin \& Urpelainen, 2018; Karapin, 2016). When are governments in advanced industrialized countries able to implement policies against interest group opposition?

Scholarship on state intervention centers on the role of state capacity, often embedded in a strong bureaucracy. A Weberian bureaucracy in particular is thought to equip the state with the ability to resist the lobby attempts of organized interests. State capacity scholars have subsequently developed a range of indicators to measure state capacity focused on characteristics of the bureaucracy, including meritocratic recruitment, levels of education, extractive capacity, and 
degrees of bureaucratic autonomy (Fukuyama, 2013). While there is little doubt that bureaucratic capacity is an essential element of state capacity, it remains an insufficient explanation for successful state intervention and the attainment of policy goals. Particularly across advanced industrialized economies, bureaucratic capacity is relatively uniform while the degree of successful policy implementation exhibits significant cross-national variation. For example, both California and Germany have advanced environmental bureaucracies, but of the two only California is on track to meet its emission reduction goals (Meckling \& Nahm, 2018b).

In this article, we argue for the need to complement bureaucratic accounts of state capacity with a political dimension of state capacity — strategic state capacity - to better understand the variation in states' ability to overcome opposition from organized interests. Strategic state capacity refers to the ability of the state - defined here as the executive and/or the legislature - to mobilize or de-mobilize interest groups in pursuit of official policy goals. The concept highlights the role of the state as an active orchestrator of its relationship with organized interests in support or opposition of state goals. We build on literatures that have begun to understand the state as an active agent in the shaping of patterns of social relations (King \& Lieberman, 2009) and identify four general types of strategies states employ to overcome interest group opposition: recruiting allies_-granting selective access and facilitating collective action among supportive interests, limiting access - constraining access for opposing interests, aligning interests - shifting preferences of interest groups toward support of state goals, and quieting interests - shifting interest group opposition to acquiescence. For each of these generic strategies, we identify a range of political tools.

Empirically, we draw on climate policy-making, a policy area rife with powerful organized interests from the energy sector, energy-intensive manufacturing industries, and related labor unions. Climate policy presents a hard test for strategic state capacity also because emissions reductions will have to come from every sector of the economy, multiplying the number of potential interest groups involved. Jurisdictions across the globe have adopted goals to reduce greenhouse gas emissions unilaterally and under the Paris Agreement of 2015. Achieving these goals requires major structural economic transformations, yet few countries are on track to reduce emissions, often as the result of backlash from organized interests. To illustrate our argument and develop a typology of strategic sources of state capacity, we draw on cases of climate policymaking in the United States, California, Germany, and France. The specific climate policy 
decisions relate to the electricity and transport sectors. These industries produce the largest share of greenhouse gas emissions and are also sectors with incumbent interests most threatened by climate policy-including electric utilities, oil and gas firms, and automakers invested in conventional engine technologies.

This article proceeds as follows. We first engage with debates on state capacity and the relationship between the state and interest groups. We then develop a typology of strategic state capacity and illustrate each of our four types of strategic sources of state capacity with an empirical case: recruiting allies - electric vehicle policy in the United States, limiting access - climate policy-making in California, shifting interests - phasing out the internal combustion engine in France, and quieting interests - phasing out coal in Germany. The conclusion puts forth areas for future research on strategic state capacity beyond the field of climate policy.

\section{State capacity and interest groups}

State capacity, defined as "the ability of the state to implement official goals, especially over the actual or potential opposition of powerful social groups" (Skocpol, 1985, p. 9), has long been a central area of inquiry in comparative politics. Research on the drivers of state capacity has examined the ability of the state to achieve desired outcomes from two central perspectives: the quality of government itself and its relationship with external interest groups.

Scholarship on the quality of government as a determinant of state capacity has placed much emphasis on the design of state bureaucracies. Such research has emphasized the importance of state autonomy, particularly in policy areas with distributional consequences that are likely to generate opposition from social groups (Carpenter, 2001; Evans, 1995; Fukuyama, 2013). Focusing frequently on the use of industrial policy, such research has identified organizational features of the bureaucracy that prevent capture by outside interests (Rothstein \& Teorell, 2008). During rapid periods of economic development in the postwar decades, Japan, South Korea, and Taiwan shared the ability to 'govern the market' (Wade, 1990) by insulating bureaucrats from industry demands, allowing governments to combine ambitious development targets with punitive measures for non-performers. High levels of state autonomy were attributed to classic characteristics of Weberian bureaucracies (Weber, 1978), including hierarchically-ranked offices, clear lines of administrative command, well-defined administrative tasks, and meritocratic recruitment (Amsden, 1989; Evans, 1995; Wade, 1990). Investments in the quality of bureaucrats 
through meritocratic recruitment subsequently became a central strategy to increase state autonomy and lower corruption in developing economies around the world (Dahlström et al., 2012; Meyer-Sahling \& Mikkelsen, 2016; Nistotskaya \& Cingolani, 2015).

A second distinct, yet related, strand of research examines forms of interest intermediation, in particular in advanced industrialized economies. Such research examines the central question of how institutions mediate the relationship between the state and interest groups. Comparativists have traditionally differentiated between two distinct institutional systems for interest intermediation: corporatism — operating through coordination and consensus between the state and key interest groups - and pluralism - featuring competitive and adversarial relations with interest groups (Dahl, 1961; Schmitter, 1977). Literatures on corporatism and pluralism have since moved beyond ideal types to identify sub-categories and hybrid modes and have distinguished between national and sectoral patterns of interest intermediation (Howell \& Givan, 2011; Kitschelt et al., 1999; Martin \& Swank, 2012). Others have distinguished between corporatism as an interest group structure and concertation as a policy-making progress involving the state and outside interests (Baccaro 2003, Ornston and Schulze-Cleven 2015).

Corporatist political systems have traditionally organized interests into a smaller number of compulsory, non-competitive, groups that have the monopoly on interest representation for their particular field. By limiting the policy-making process to a single forum, corporatist states can forge coordination and agreement between various external constituents in the pursuit of common goals (Schmitter, 1977, p. 13). Scholars have argued that corporatist systems-whether at the national or sectoral level-can be more effective at encouraging complex industrial transformations (Jasanoff, 1985), focus on long-term goals rather than particularistic interests, provide public goods, and are more capable agents of change through the compensation of losers (Hatch, 1995; Lundqvist, 1980). In this view, policymakers in corporatist systems are capable of developing policies that reflect autonomous bureaucratic and legislative agendas (Skocpol, 1985).

Critics have argued that classic notions of corporatism overestimate the strength of the state vis-à-vis business (Samuels, 1987) and underestimate the growing influence of business on policy design and its dominance over labor (Streeck, 2016). Research has also shown significant crosssectoral variation in the degree of corporatism within countries (Meckling \& Nahm, 2018a). Corporatist accounts of interest intermediation pay less attention to the politics through which the state actively reproduces or transforms stable state-interest group relations. As we show here, 
however, even states with corporatist characteristics nonetheless exhibit a range of strategies with which they further embed or dis-embed themselves in interest group relations, highlighting the need to complement institutionalist accounts of state capacity with strategic dimensions of interest group politics.

In pluralist political systems, by contrast, interests are organized in multiple, voluntary, and non-hierarchical groups, which do not have a monopoly on interest representation and compete with other groups for political influence (Schmitter, 1977, p. 15). Conventional thought holds that pluralist states have little capacity to resist interest groups (Dahl 1961). The United States, for example, has been famously described as internally weak in its economic policy-making (vis-àvis interest groups), but strong vis-à-vis other countries (Krasner, 1978). The permeability of pluralist states to interest groups renders them vulnerable to capture by private sector oligopolies (Gilens \& Page, 2014). Pluralist states are thus conceptualized as fora for interest group competition, appear poorly equipped to drive state-led economic change, generally leave little space for activist policymakers (Atkinson \& Coleman, 1989, pp. 52-53; Skocpol, 1980, p. 157). Yet, research on, for example, the US presidency and the European Commission demonstrate a surprising level of independent policymaker preferences and government activism, even in pluralist settings (Weir and Skocpol, 1985; Vogel, 2012). Political competition among interest groups offers opportunities for governments to shape the broader interest environment in pursuit of the government agenda.

More recently, historical institutionalists have examined the question of interest intermediation in the context of institutional complementarities. Interlocking institutional arrangements have yielded state capacity suitable for different types of policy interventions against opposition of outside interests. Research in the tradition of the Varieties of Capitalism has distinguished between liberal and coordinated market economies, each capable of advancing different types of policy goals ranging from welfare policy to technological innovation as a result of divergent institutional strengths and patterns of social relations (Hall \& Soskice, 2001). Subsequent work has shown that such institutions evolve in response to changes in the global economy and other external challenges, but maintain divergent institutional strengths and relationships with societal interests (Le Galès \& King, 2017; Steinmo, 2010; Thelen, 2014). While the Varieties of Capitalism school of thought adopts a relational view which we share, it also puts forward a very structuralist reading of institutional effects. In advancing the notion of strategic 
state capacity, we instead highlight the strategic discretion of state actors in shaping state-business and state-society relations.

\section{Strategic sources of state capacity}

Strategic capacity is an understudied dimension of the state's ability to pursue policy goals against the opposition of powerful interest groups. When it comes to the state and strategy, political science research generally focuses on foreign policy, strategy vis-à-vis other countries. Although the state's internal strategy toward interest groups currently lacks terminology and scholarly attention, research on social movements, for instance, has highlighted the importance of strategic capacity to achieve movement goals (Ganz, 2000b: 1009).

We develop the concept of strategic capacity in the context of states' relationships with interest groups as a missing dimension in existing institutional approaches. We understand the state to encompass the executive and its bureaucracies and the legislature along with legislative staff. At its core, strategic state capacity refers to the ability of the state - the executive and/or the legislature - to mobilize or de-mobilize interest groups in pursuit of official policy goals. It encompasses the state's strategic embedding and dis-embedding with interest groups, depending on policy targets and interest group preferences in relation to these goals. Our argument resonates with Daniel Carpenter's (2001) idea that state capacity can be explicitly political: state autonomy is not fully vested in static institutional features but additionally relies on coalition-building. While Carpenter focuses on how bureaucrats build coalitions to gain autonomy from the legislature, we focus on how the state - including bureaucrats and legislators - manages interest groups to pursue policy goals. Our work shares with Carpenter the assumption that external interests are diffuse and not uniformly opposed to state goals. Both executive agencies and legislators seek out interest group support in policymaking, strategically exploiting differences among external interests to advance government agendas. Sets of state actors with heterogeneous agendas also compete in enlisting interest group allies.

We develop a typology of four ideal types of state strategies vis-à-vis interest groups that can be observed across institutional contexts. They encompass both general strategies and specific tools government actors leverage in managing external interests. We distinguish ideal types, even if in practice states often draw on multiple strategies at once. We identify two dimensions along which state strategies toward interest groups differ: mobilizing/de-mobilizing effects and 
influence/preference effects. First, since some interest groups may share state goals, while others do not, state actors either attempt to mobilize interest groups in support of their agenda or they seek to de-mobilize external opposition. State actors can organize supporting interests to build a winning coalition, or they can attempt to limit the access or quiet interest groups opposing state goals. We emphasize the agency of the state in recruiting groups or in restricting access to the policymaking process for particular interest groups. Corporatist systems of state-business relations can be a means of limiting the political influence of newcomers, but policymakers can also strategically use corporatist institutions to actively bring in new societal interests and diminish the influence of incumbents. In Norway, for instance, the state actively organizes and funds societal interest groups. Likewise, pluralist states can passively respond to competing interests, or they can actively intervene to mobilize and de-mobilize different groups. Britain under Thatcher actively sought to undermine societal groups and created obstacles for civic associations (Dryzek et al., 2002).

Second, state actors can seek to shift the balance of influence among interest groups (influence effect) or to shift the preferences of interest groups (preference effect). If preferences are assumed to be fixed, policymakers may aim to enhance the influence of supportive organized interests, while limiting the influence of opposing groups. Policymakers may, however, also seek to change preferences. Preferences of interest groups are not just determined by underlying material interests but also shaped by their political context, expectations of future developments, as well as ideas and values. Institutionalists have long challenged the assumption underlying behavioral political economy that actions reveal preferences, arguing instead that institutions shift expressed preferences even when underlying interests are unchanged (Immergut, 1998). Groups may not always be aware of their material interest, or may shift their preferences over time as a result of politics (Woll, 2008). But state strategies can also change the underlying material interests of social groups. This can occur when policies change the costs and benefits that societal groups receive, or through bargaining, for instance when the state buys acquiescence through direct compensation. In short, strategies focused on affecting the influence of interest groups take interest group preferences as given, while strategies centered on shifting preferences either seek to quiet opposition through bargaining or broaden the set of supportive interests through changes to the balance of material benefits. 
Table 1 State strategies toward interest groups

\begin{tabular}{|l|l|l|}
\hline & Mobilizing effect & De-mobilizing effect \\
\hline Influence effect & Recruiting allies & Limiting access \\
\hline Preference effect & Aligning interests & Quieting interests \\
\hline
\end{tabular}

These two dimensions offer four general types of state strategies: recruiting allies, limiting access, aligning interests, and quieting interests (Table 1). For each of these overarching strategies, policymakers can several political tools (Table 2). We now turn toward discussing each type of strategy and related tools.

Recruiting allies: In democratic political systems, the executive and the legislature require some societal support to pursue independent policy preferences. They can mobilize support by recruiting allies prior to a policy decision to shift the balance of power among competing interest groups without changing underlying preferences. We highlight two tools to achieve this objective: interest-shopping and coalition-building. Interest-shopping refers to policymakers giving greater access and prominence to select interests that align with policymaker preferences (cf. Swenson, 2018). Although the existing literature has focused on forum-shopping - which refers to interest groups seeking the political forum that offers them greatest influence-policymakers can equally engage in interest-shopping to maximize interest group support. Coalition-building builds on interest-shopping but places policymakers in the role of a broker that enables collective action among organized interests. While many coalitions form through bottom-up association by interest groups, policymakers can create a forum for interest groups and actively broker coalitions for policy decisions.

Limiting access: When interest groups oppose a policy proposal and their preference cannot be easily changed, policymakers may seek to limit access to opposing interests to tilt the balance of power in favor of supportive interest groups. A broad range of tools are available to achieve this goal, though we focus here on two: delegation and individual negotiations. Parts of government that are highly permeable to interest group influence can delegate policy decisions to more insulated parts of government - government bureaucracies in particular — thereby limiting access and exploiting the relative autonomy of individual state agencies (Meckling \& Nahm, 2018b). 
In particular, the legislature may delegate specific policy decisions to government bureaucracies to avoid capture of the more permeable legislature by outside interests. Government bureaucracies tend to exhibit greater autonomy from interest groups than legislatures for reasons related to resources and incentives (Carpenter, 2001; Potoski \& Woods, 2002). Legislators are incentivized to secure benefits for interest groups, as they depend on campaign financing and constituency support for re-election. Bureaucracies, by contrast, are primarily staffed with career bureaucrats who tend to pursue the agency mandate (Dixit, 2002). Bureaucracies can also possess reputational and knowledge resources that strengthen their autonomy from organized interests (Huber \& Shipan, 2002). Legislatures, instead, often have fewer technical staff than agencies and rely on outside groups for expertise. Legislatures can delegate policymaking tasks with distributional effects to bureaucratic agencies, particularly those relating to distributional decisions that tend to mobilize interest groups and stoke public opposition. Policymakers can also limit access by negotiating with opponents individually instead of collectively. This may allow policymakers to accommodate individual opponents' concerns and to strike differential bargains with powerful opponents to undermine a unified opposition.

Aligning interests: While the previous two overarching strategies assumed fixed preferences, policymakers can also seek to shift interest group preferences to align with their political goals. While aligning interests has the same goal as recruiting allies-building interest group support for state goals - it focuses on changing preferences rather than organizing interests that are already supportive of state goals. Shifting preferences in the near term often involves bargaining tools, such as financial incentives, to establish support for a policy decision among opposing interests. Policymakers can also seek to shift preferences over time through two strategies in particular: triggering policy feedback and political signaling.

An important literature has examined policy feedback that occurs when an initial policy choice generates increasing returns for social groups, thereby changing the preferences of political actors over time. Initial policy decisions can provide benefits to voters who subsequently mobilize and help entrench the policy. A classic example is the mobilization of senior voters after the introduction of social security (Campbell, 2002). Recent work has expanded the study of policy feedback beyond voters to interest groups (Hertel-Fernandez, 2018; Meckling and Trachtman, 2021; Trachtman, 2021). For example, the introduction of renewable energy policies in US states led, in a number of cases, to the emergence of business coalitions that helped entrench and expand 
these policies (Stokes, 2021). New research suggests that policymakers may in fact strategically "use policies to structure future politics to their own advantage" (Anzia \& Moe, 2016: 763), for instance when Democratic politicians in the US deliberately adopted public-sector collective bargaining laws that led to the rise of Democratic-leaning public-sector unions.

A second tool to shift preferences over time is political signaling to affect interest group expectations before actual policy development (Weiss, 2013). States use political signals to declare commitment to policy goals, in particular in contexts that require coordination among multiple actors (Wolford, 2014). The central notion is that one party has greater information than others and signals private information to select counterparts (Bailey et al., 2005). While signaling itself demands little financial and political capital, the credibility of such signals can vary significantly depending on underlying policies to implement the policy goals (Horowitz et al., 2017). Although political signaling theory conceptualizes signaling as government-to-government communication, states can also use signaling to address interest groups. One example is long-term target-setting through greenhouse gas emission targets: depending on the credibility of the signal, states shape long-term expectations for interest groups to which they can slowly adapt, reducing future opposition to eventual policy implementation.

Quieting interests: Turning opponents into supporters is challenging. When bargaining cannot shift preferences, the best policymakers can often hope for is to buy acquiescence from opposition groups. The prevalent-if costly-tool to achieve consent is compensation. Governments have long compensated opposing constituencies to reach policy goals, particularly during periods of structural economic change when declining industries have demanded government protection. Sectors such as shipbuilding, textiles, and mining have suffered from dwindling comparative advantages in advanced industrialized economies and received adjustment subsidies and transfer payments in exchange for political acquiescence. The size and type of compensation offered have depended on the clout of the industrial labor force and the degree of industry concentration, with large, highly concentrated industries often avoiding the need for compensation altogether by successfully demanding government protection from the forces of structural decline (Uriu, 1996, p. 12). 
Table 2 Strategies and tools

\begin{tabular}{|l|l|}
\hline Strategy & Tool \\
\hline \multirow{2}{*}{ Recruiting allies } & Interest-shopping \\
\cline { 2 - 2 } & Coalition-building \\
\hline Limiting access & Delegation to agencies \\
\cline { 2 - 2 } & Individual negotiations \\
\hline Aligning interests & Triggering policy feedback \\
\cline { 2 - 2 } & Political signaling \\
\cline { 2 - 2 } & Incentives/buying interests \\
\hline Quieting interests & Compensation \\
\hline
\end{tabular}

The list of tools discussed is by no means exhaustive. The strategies in table 1 are sufficiently broad to account for several different tools and tactics that further empirical research will shed light on. It is also important to note that these strategies are analytically distinct but work in tandem or sequentially in political practice. For example, aligning interests may be pave the way for recruiting allies. While policymakers work actively toward building a support coalition, they may at the same time try to quiet opposing interests through compensation.

In this article, we focus on identifying key strategies policymakers use to manage organized interests. Yet the introduction of the notion of strategic state capacity raises three central questions on (1) the sources of strategic capacity, (2) the choice of strategies/tools, and (3) the effectiveness of strategies/tools. We offer arguments on what sets of variables may help answer each of these questions, while also spelling out research agendas for each in the conclusion. First, we suggest that individual-level and organization-level differences account for variation in strategic capacity. Research on social movements has, for example, show the importance of the life experience and networks of policy entrepreneurs and the deliberative processes and resource flows of their organizations as key sources of variation in strategic capacity (Andrews et al., 2010; Ganz, 2000a, 2009). This remains an important research desideratum, including the question whether variation in strategic capacity occurs primarily within states (and across different state actors) or across states.

Second, we propose that cost and institutions may condition when policymakers choose one strategy over another. Strategies vary in their costliness to policymakers. Cost can entail the 
risk of political backlash or actual budget costs that represent trade-offs to pursue other political goals. The alignment of interests through financial incentives and the quieting of opposition through direct compensation, for instance, have immediate fiscal consequences. Similarly, domestic institutions are likely to provide opportunities or constraints for different strategies, including the ability to compensate interest groups and to delegate policy implementation to autonomous bureaucracies (Finnegan et al., 2021).

Third, strategies and tools are likely to vary in their effectiveness. This may be both a function of characteristics of the tool itself and the opportunity structure of the interest group landscape. For example, political signaling is less likely to be effective as it relies on the mere credibility of political signals to change the preferences of outside groups. Delegation to bureaucratic agencies and the direct compensation of outside groups, by contrast, guarantee stronger and more permanent results by changing actual payoffs. The social movement literature suggests that the broader political opportunity structure also conditions strategy effectiveness, in particular the distribution and strengths of preferences across interest groups.

While we treat these three questions as analytically distinct, they intersect in the situation of strategic choice. It is important to note that policymakers may face trade-offs, for example, between cost and effectiveness. Compensation is costly, but likely scores high on effectiveness. We will return to these three questions in the conclusion.

In the following, we illustrate each type of state strategy with an important case of climate politics in Europe or the United States. The cases informed our theory development inductively. As such, our cases represent ideal cases of our typology. We focus on establishing internal validity through process-tracing, counterfactual analysis, and within-case inter-temporal comparisons where possible. Given the inductive research design, our ability to establish external validity is limited, although we observe our cases across divergent institutional contexts. The cases offer critical variation in types of interest intermediation - pluralist versus corporatist settings, which shows that strategic state capacity is not just complementary to pluralist institutions.

Data comes from government documents, newspaper coverage, and industry journals, as well as 61 interviews conducted between 2016 and 2017 with policy-makers (22), representatives from firms and industry associations (24), non-governmental organizations (10) and expert advisors (7) involved in climate policy in Europe and the US. We used background interviews to inform the overall argument but rely primarily on print sources for citation. 


\section{Strategic state capacity in climate politics}

Climate politics is distributive politics, with the potential to impose significant costs on powerful interests (Aklin \& Mildenberger, 2020; Colgan et al., 2021). Climate policy-making inevitably mobilizes vested interests across a range of energy and energy-intensive legacy industries and thus represents a hard case for state capacity. We focus here on climate and clean energy politics to illustrate the four general strategies that states use to implement policy preferences against opposition from outside interest groups (see Table 1). Our cases draw on climate policy in general and on specific climate policy measures for the electricity and transportation sectors, the two largest contributors to greenhouse gas emissions. Our electricity case relates to phasing out coal in power generation, while the transportation cases engage with the vehicle electrification.

\section{Recruiting allies: Coalition-building for electric vehicle policy in the United States}

Policymakers and experts increasingly see the electrification of transport as central to climate policy. This means taking on powerful legacy automakers who have invested for decades in technical expertise and manufacturing capacity for the internal combustion engine. In the US, Congress introduced several tax credits that incentivized the commercialization of hybrid and electric vehicles in the 2000s. In the pluralist system of the US, policymakers have limited ability to quiet interest through compensation given the lack of ongoing bargaining relationships with economic interest groups. Similarly, the scope for limiting access is constrained in transport policy given the lack of agencies with sufficient bureaucratic autonomy to insulate policymakers from business backlash. Given this institutional landscape, activist policymakers and legislative staffers resorted to recruiting allies in a contested landscape of interest groups to pass these policies. We show how recruiting allies entails both granting privileged access to organized interests and brokering collective action.

US policy-makers initially gained interest in promoting alternative transport technologies after 9/11, largely to reduce oil imports (Meckling \& Nahm, 2018a). President George W. Bush developed the vision of a hydrogen economy (Hultman \& Nordlund, 2013) and increased public funding for research and development on the hydrogen fuel cell through the Department of Energy (Canis, 2011). This included initiatives in which the government collaborated with Daimler, Ford and GM on fuel cell research and development (Department of Energy, 2006). At the time, a loose bipartisan coalition of security and environmental interests was in favor of promoting advanced 
transport technologies. In the aftermath of 9/11, national security circles were increasingly propelled by the idea of oil independence. These interests aligned with environmental goals. It is against this background that Senate staffers set out to craft a support coalition for consumer incentives for alternative transport technologies.

The Energy Policy Act of 2005, the first major energy bill in a decade, offered the opportunity to advance policy for advanced transport technologies. As part of the bill, the CLEAR Act introduced consumer tax credits for hybrid cars and plug-in hybrids, cars that have both an internal combustion engine and an electric engine. The introduction of tax credits for hybrid cars was the first time the US government promoted the commercialization of technologies competing with the internal combustion engine. It was the result of coalition-building by two senators in the face of significant opposition. Senators Orrin Hatch (R-UT) and Susan Collins (R-ME), who sponsored the bill, carefully crafted a support coalition among industry, environmental, and security interests (Collins, 2005). Senator Hatch's office took an early lead in pulling together key groups. Senator Hatch was interested in reducing air pollution from transportation in Utah. The state's two biggest counties sit in bowls that often trap the air. Jared Brown, Senior Energy Advisor to Senator Hatch and long-time legislative staffer, argued: "Every staffer is afraid of [...] exposing their boss to public pushback. With a large coalition, you already have that backing." 3 Brown worked closely with major environmental groups, such as the Union of Concerned Scientists and the Environmental Defense Fund, and with the Electric Drive Transport Association (EDTA), the trade group lobbying for support policies for electric cars (Taylor, 2009). He organized the meetings and selected participants in ways that balanced the representation of business and environmental interests, while ensuring sufficient alignment of interest to broker a durable alliance. Brown commented that "it became very tricky to hold that coalition together," reflecting his active role as coalition broker. ${ }^{4}$ Among automakers, only Ford, Toyota and Honda were part of the alliance (Clear Act Coalition, 2003). Toyota was a particularly strong supporter of the tax credit given its market leadership in hybrid car technology. By contrast, GM, the largest domestic automaker, was not invited to join the meetings. GM's technology strategy focused on hydrogen fuel cells as a long-term alternative technology and was thus not aligned with the push for electric vehicles. It hired top Republican lobbyist Tom Korologos to prevent the inclusion of tax credits.

\footnotetext{
${ }^{3}$ Interview with Jared Brown, Policy Advisor for Senator Orrin Hatch (September 8, 2016).

${ }^{4}$ Interview with Jared Brown, Policy Advisor for Senator Orrin Hatch (September 8, 2016).
} 
At the same time, Volkswagen, also not invited, was pushing for incentives for advanced diesel technologies, as was Chrysler. ${ }^{5}$ It was tricky for staffers to maintain the coalition against GM's opposition in particular, but legislative sponsors stayed the course and continued to support the tax credit. ${ }^{6}$ The case reflects a remarkable level of select recruiting that staffers engaged in, even limiting access to the meeting to the largest domestic auto producer. Demands from other interest groups to join the meetings and coalition existed: "People kept coming at us, wanted golf carts included. We needed to put up a fence around the purpose of the coalition. We wanted to change transportation," Brown said. ${ }^{7}$ Ultimately, Senate staffers had successfully brokered a minimal winning coalition that led to policy that helped commercialize hybrid cars, resulting in market competition for the internal combustion engine. What Senate staffers had accomplished for hybrid cars in 2005, they repeated for electric cars in 2008.

During the economic crisis of 2008/09, the US government's multi-pronged strategy for advanced transport technologies transformed into a major push for electric cars. The first step was to introduce an electric vehicle tax credit. The Emergency Economic Stabilization Act of October 2008, the first and smaller stimulus package, adopted consumer tax credits for plug-in batteryelectric vehicles. The tax credit was up to USD 7,500 with an industry cap of 250,000 cars that could receive the credit. Senators Hatch (R-UT), Cantwell (D-WA) and Obama (D-IL) had already proposed the EV tax credit in the Freedom Act of 2007, but the credit did not pass at the time. The effort continued Senator Hatch's leadership on the CLEAR Act of 2005. As in 2005, staffers of Senators Hatch and Cantwell strategically built a support coalition for the proposal, rather than responding to demands from industry. ${ }^{8}$ Jared Brown now invited GM into the coalition, as it was developing its first electric model, the Chevrolet Volt. He said that the goal was to implement the tax credit by the time the Volt launched. The Volt itself was "calculated to position GM as the chief partner in Washington's emerging green industrial policy" (Dalmia \& Payne, 2009). The first meeting to develop a coalition for EV tax credits occurred in 2006 and Brown had to persuade advocates such as Genevieve Cullen, head of EDTA, to join the alliance, as EDTA was not yet certain that batteries had reached sufficient maturity for a mass market push. This shows the active recruitment necessary to broker political support. Toyota was again engaged - it had started to

\footnotetext{
${ }^{5}$ Interview with industry representative (November 1, 2016).

${ }^{6}$ Interview with Jared Brown, Policy Advisor for Senator Orrin Hatch (September 8, 2016).

${ }^{7}$ Interview with Jared Brown, Policy Advisor for Senator Orrin Hatch (September 8, 2016).

${ }^{8}$ Interview with senior legislative staffer (September 6, 2016).
} 
explore the launch of a plug-in hybrid vehicle. Other key supporters were the Auto Alliance, the electric car and battery start-ups Tesla and A123, and key environmental groups such as the Union of Concerned Scientists and the Environmental Defense Fund. With this cross-cutting coalition as support, Senator Hatch could sell the tax credit to Republicans. Yet, it took a lot of energy from staffers to maintain the coalition. For example, they had to convince EDTA that the time was right for a plug-in electric vehicle tax credit. Senate staffers also tried to recruit electric utilities to support the bill, but did not get much political capital from the American Public Power Association and the Edison Electric Institute. These groups went along with the bill but were not strong advocates. Among environmental groups, the Sierra Club defected from the coalition. ${ }^{9}$

Ultimately, however, the strategically crafted baptist-and-bootlegger coalition of environmentalists and select industry actors proved sufficient for the passage of EV tax credits. Legislative staffers in particular had orchestrated interest group support through select recruitment, rather than simply responding to competing lobbying requests or a coalition that formed among interest groups. The American Recovery and Reinvestment Act of 2009, the major stimulus bill, expanded the consumer tax credit for plug-in electric cars significantly. It has since been a major policy incentive for the uptake of EV sales in the United States.

Would the broad coalitions have emerged in the absence of legislative staff adopting the role of broker? We cannot fully answer this question, but there are reasons to believe that the convening power and strategic selection by state actors was instrumental. The interest groups were very diverse and not all of them natural allies, especially environmental interests on the one hand and security and industry interests on the other. Bipartisan leadership by state actors created a setting of trust in which they could come together. Also, the staffers' selection of individual auto firms whose technology strategy aligned with the push for EVs and hybrids was essential to orchestrating a reform coalition. In the absence of such state actors, auto firms might have gravitated toward collective lobbying through their sectoral trade association. State strategies focused on "recruiting allies" may shift the rationale for firms to break from collective industry lobbying.

\footnotetext{
${ }^{9}$ Interview with Jared Brown, Policy Advisor for Senator Orrin Hatch (September 8, 2016).
} 


\section{Limiting access: Delegating climate policy to a powerful agency in California}

Comprehensive climate legislation is necessary to achieve ambitious climate goals, yet generates opposition from incumbent interests in a range of industrial sectors concerned about future competitiveness and the possibility of stranded assets. In California, perhaps the jurisdiction with the world's most ambitious climate goals, opposition to climate policy has come from heavily emitting producers in sectors ranging from energy and transportation to agriculture, both in California and in the United States more broadly. Given the size and political clout of these interests, buying acquiescence through compensation is financially very costly. Policymakers could recruit allies in local clean energy sectors, but given the critical role of California in setting broader standards for the United States (Meckling \& Nahm, 2018b), local clean energy groups are unlikely to outweigh the opposition of well-resourced national fossil fuel supporters active in California politics. Facing an overwhelming coalition of fossil fuel interests in a pluralist institutional setting, California's legislature instead resorted to limiting access, deliberately delegating the policymaking process to an autonomous expert bureaucracy. Legislators sought to avoid legislative debates about the emissions reductions burden for individual sectors of the economy.

The California legislature used a strategy of limiting access in the design and implementation of its signature climate policy, AB 32, which in 2006 set the goal of reducing statewide emissions levels to 1990 levels by 2020. Key to California's ability to limit the influence of outside interest groups on climate policy design and implementation was a division of labor between legislators and bureaucrats in the state government. The legislature, more vulnerable to interest group influence, focused on setting overall emissions reductions goals, but strategically delegated politically contentious decisions about policies to meet these targets to be resolved by an independent regulatory agency, the California Air Resources Board (CARB) ${ }^{10}$ By limiting public debate in the legislature to setting overarching emissions reductions goals without addressing required contributions from individual sectors of the economy, the legislature distanced

\footnotetext{
${ }^{10}$ Interviews with Senior Counsel to California Senator (June 28, 2016), former Air Pollution Specialist, California Air Resources Board (May 27, 2016); Director, Energy and Transportation Program, NRDC (May 27, 2016); Bill Magavern, Policy Director, Coalition for Clean Air (May 26, 2016).
} 
itself from sectoral interest group pressures and obfuscated emissions reductions quotas required by individual industries.

Climate policymaking occurred in two distinct stages. First, AB 32, the Global Warming Solutions Act, was introduced by Democratic House members Fabian Núñez and Fran Pavley in April 2006. Only ten pages long, the bill set GHG reductions targets without explicitly mentioning or prescribing sectoral policy measures (Carlson, 2012). The legislature was subject to active interest group battles over the stringency of climate legislation. On the side of the Democrats, which favored a strict regulatory approach to emissions reductions, were Silicon Valley tech firms, clean energy associations, the ski industry, as well as labor unions and environmental movements. Arguing against economy-wide climate targets were the California Chamber of Commerce, industry associations for manufacturing, fossil fuel, and the retail industry, as well as the U.S. auto lobby which feared that stringent California targets would eventually become the national standard (Karapin, 2016, p. 114). While business interests were divided on the bill, debates avoided distributional arguments over contributions from individual sectors of the economy (Karapin, 2016, pp. 156-161).

AB 32 passed along party lines and strategically appointed CARB as the implementing agency. It provided the $\mathrm{CARB}$ with sweeping regulatory authority to develop and implement a set of comprehensive policy measures that would allow the state to meet the goals set in the legislation (State of California 2006). The bill deliberately contained no concrete policy measures to avoid stirring up interest group opposition. AB 32 instead provided a set of deadlines for CARB to establish an overall emissions budget, defined a reporting rule for GHG emissions, and required CARB to present an economy-wide scoping plan for how emissions reductions goals could be achieved (State of California, 2006). CARB's subsequent scoping plan included 18 emissions reductions policies that covered virtually all sectors of the economy, including the largest emitters, transportation and electricity. CARB also decided to set up a statewide carbon trading system that would eventually cover 85 percent of California's carbon emissions (CARB, 2008). ${ }^{11}$

Although AB 32 conferred regulatory authority over emissions reductions to CARB, the agency was nonetheless required to seek public input. The scoping plan was subject to a period of public commentary, yet CARB was not legally mandated to act on public comments. CARB

\footnotetext{
${ }^{11}$ Interviews with Executive Director, Electric Vehicle Industry Association (May 25, 2016); EV program manager, California electric utility (July 1, 2016).
} 
received over 43,000 comments on the document and solicited external advice through community meetings, technical workshops, and expert commentary (CARB, 2008). Nonetheless, the scoping plan became a target of industrial lobbies, which unsuccessfully sought to challenge CARBs policies in court (California Air Resources Board, 2017; Carlson, 2012, pp. 77-78). By 2012, the vast majority of policy measures proposed by CARB had been implemented, allowing for California's rapid progress toward its emissions goals without political interference from industrial lobbies.

Designating CARB as the implementing agency to achieve these outcomes was a strategic choice to limit the political influence of interest groups. Pavley, the author of the bill, "expressed certainty that the bill might never have passed had it contained a detailed plan for reducing emissions," emphasizing the deliberate delegation to CARB as a political strategy to avoid political interference (Carlson, 2012, p. 79).

\section{Aligning interests: Political signaling to phase-out dirty cars in France}

As transportation-related emissions have continued to rise and now make up roughly 25 percent of global carbon emissions (UNFCC, 2019), policymakers around the world have sought to shift transportation to cleaner sources of fuel (Meckling and Nahm, 2019). In France, as in other economies, such policies have met vocal opposition from automakers invested in existing transportation technologies, oil companies supplying for the current vehicle fleets, and labor unions concerned about employment effects of technological change. The French government's close relationship with its large automotive groups, Renault and Groupe PSA, jointly responsible for seven percent of global auto manufacturing, long prevented ambitious policies to support vehicle electrification. Buying acquiescence through compensation promised to be financially costly, while in the past limiting access had proven difficult given the political and financial clout of the highly concentrated automotive industry. The government opted to attempt to align private sector interests through political signaling, a low-cost strategy of shift the preferences of existing automakers by signaling future policy trajectories.

A long-term auto exporter, France in 2016 ranked $11^{\text {th }}$ among car exporting nations (United Nations, 2018). The continued competitiveness of the domestic auto industry in global markets likely to shift to electric vehicles was a priority for the French government, which had made two previous attempts to promote the development of domestic electric vehicles. In 1995 and again in 
the late 2000s, the state attempted to develop electric vehicle markets, yet both times automakers were able to block ambitious policies. As a result, the rate of transportation electrification was very slow: By 2002, only 7,500 electric vehicles were registered domestically, far short of the initial goal of 100,000 registered EVs by 1999 (Calef \& Goble, 2007). Policies became more ambitious after the 2008 financial crisis, when the French government passed a first tax break for electric vehicles as part of broader stimulus efforts. More aggressive incentives ensued in 2012 and 2015, including a purchase grant and reductions to vehicle tax. While such policies helped France become the second largest domestic EV market in Europe after Norway by 2016, overall EV registration numbers remained low and domestic automakers remained divided in their approach to vehicle electrification (Tietge et al., 2016).

After decades of resistance, Renault in the late 2000s became more receptive to electric vehicle policies after it gained access to new engine and battery technologies through its strategic alliance with Nissan. In 2010, it began releasing a number of Renault-branded EVs which were largely based on Nissan technologies. Seeing a potential competitive advantage, Renault abandoned opposition to more stringent emissions regulations and subsidies for electric cars (Chrisafis \& Vaughan, 2017). Yet France's other domestic auto group, Groupe PSA, lagged in the development of electric vehicle technologies and remained hostile to technological change. Groupe PSA, which makes Peugeots and Citroëns, was facing significant investments in the development of new technologies, with uncertain prospects in international markets. Groupe PSA spokeswoman, Laure de Servigny, maintained that the company would continue to prioritize vehicles with traditional combustion engines, particularly for sale in foreign markets (Held, 2017).

Industry support for future emissions reductions from the automotive sector hinged on the technology portfolios of domestic automakers, in particular Groupe PSA. To shift its preferences and motivate investments into electric vehicle technology that could pave the way for future regulations, the French government in 2017 announced the ban of gasoline and diesel cars by 2040 (Ministry for the Ecological and Inclusive Transition, 2017). The goal was codified into law in 2019, adding further credibility to the targets as part of France's strategy for reaching net-zero emissions by 2050 (Reuters, 2019). In the same year, Groupe PSA announced that, starting immediately, all new vehicle models would also be offered as plug-in hybrid or all-electric versions, creating an electric option for its entire portfolio by 2025 (Groupe PSA, 2019). France explicitly justified this goal in terms of continued industrial leadership: "stopping sales of petrol 
or diesel cars will encourage car manufacturers to innovate and take the lead on this market" (Ministry for the Ecological and Inclusive Transition, 2017). In addition, the climate plan noted that the French Government is "laying the foundations of a new model of prosperity [by] seizing the opportunities before us in terms of innovation, investment and job creation."

The French government used political signaling to encourage political momentum behind the electrification of the transportation sector and thereby reduce the likelihood of future interest group battles. "The point is ... how much time you give the industry to adapt to this situation and how much time you give the industry to train people to different jobs or readjust their company to this different reality," Tavares, the CEO of Groupe PSA, said in response to government phaseout signals (Noble, 2020). Against the divided strategies of domestic automakers, France's phase-out announcement served two broad goals. First, by signaling future policy support for vehicle electrification and a ratcheting of domestic requirements, the phase-out target, even if not implemented in policy, assured EV-skeptical automakers that investments in new vehicle technologies would pay off. The ban announcement was an attempt to shift the preferences of firms in the domestic auto sector by signaling the direction of future policy developments, making continued investments in traditional vehicle technologies look unattractive. Second, after decades during which the state had coalesced with domestic automakers around transportation policy, the ban announcement sought to mobilize the domestic auto industry in support of public policy goals that the state could not achieve through consensus. The phase-out target was a low-cost strategy to shape long-term expectations for automakers to which they can slowly adapt, reducing future opposition to eventual policy implementation.

\section{Quieting interests: Compensation politics in phasing out coal in Germany}

Next to phasing out dirty technologies, climate policy increasingly focuses on phasing out coal in electricity generation. It is the most carbon-intensive fuel for power generation. Phasing out coal entails taking on utilities, independent power producers, and mining companies who have assetscoal plants or reserves - that they could continue to run and monetize for years. Over the last few years, a number of countries adopted moratoriums for coal mining or plans to phase out coal-fired electricity generation (Blondeel \& Van de Graaf, 2018). Among them, Germany's plans stand out, given significant domestic lignite mining and a broad set of vested interests in coal. Germany exhibits corporatist patterns of state-business relations with limited bureaucratic autonomy and 
could thus not easily limit access to incumbent producers. The government could also not flip opposing interests to become strong allies even though it had pursued an ambitious renewable energy policy for years. Coal assets simply remained a significant enough asset for electric utilities to defend coal. This left the government with the strategy to seek acquiescence from opponents through compensation. While the country has long-standing bargaining relations between business and government, it was not locked into a specific bargaining forum. Instead, the state strategically created a new forum for negotiation and bargaining with incumbent interests in the energy sector, while also brining in new interests.

While Germany has promoted renewable energy for decades, it also continued to support coal mining and coal-fired power generation (Renn \& Marshall, 2016). Yet in the mid-2010s it became increasingly clear that the country would fail to reach its emission reduction target for 2020. Coal-based power generation was a key culprit. In the 2017 coalition negotiations after a general election, the Conservatives (CDU) and the Social Democrats (SPD) negotiated the goal of phasing out the burning of coal in the country.

Turning phase-out goals into policy promised to become a major battle, with coal regions, electric utilities and labor unions fighting back. Drawing on its corporatist tradition, the government created the "Commission for Growth, Structural Transformation, and Employment" (known as "coal commission"). The government appointed 31 representatives of industry, German states, labor unions, environmental groups and science in June 2018. The government selected individuals with a view to both representation of key groups and to bringing together individuals who knew each other and had long-standing working relations. ${ }^{12}$ It mandated the commission to develop a policy proposal for how to phase out coal in Germany's electricity mix, achieve the 2030 emission reduction targets for the power sector, and create employment in regions impacted most by the coal phase-out. The mandate specifically included public investments in economic transition (Bundesregierung, 2018).

The commission met throughout half a year. Conflict ensued over who would get compensated how much. At this point, Olaf Scholz, the finance minister, spoke to the commission, clarifying the conditions under which the government was willing to provide funds. It was willing to compensate regions, but not electric utilities. The commission's final recommendations envisioned a coal phase-out by 2038 , tied to a 40 -billion-euro public investment package for the

\footnotetext{
${ }^{12}$ Interview with representative of German Federal Ministry of Finance (August 30, 2019).
} 
compensation of those bearing the costs of the transition. This includes coal-mining regions, energy-intensive industry, electric utilities operating coal-fired generation plants, and coal workers. The German Association of Energy and Water Industries concluded that the compromise provided planning certainty for investments in the electric utility sector. The IG Bergbau, Chemie, Energie, a major labor union covering the coal mining industry, said that that the commission's report succeeded in protecting impacted workers from economic hardship (Handelsblatt, 2019). The deal proposed by the commission thus did not turn opponents into supporters, but succeeded in quieting the opposition through compensation.

While the federal government was not bound by the commission's outcome, it largely adopted the "coal consensus" and submitted a bill to German parliament in summer 2019 to turn the recommendations into legislation. At the same time, the finance ministry provided 240 million of immediate funds, before the full compensation package would enter into force in 2020 (Schwarz, 2019). After decades of resistance from coal interests, the government's targeted compensation politics overcame the long-standing opposition to phasing out coal. Counterfactual analysis underlines the centrality of compensation to achieve the coal phase-out. Prior to the compensation-based deal, the German government was keenly aware of how coal-fired electricity generation contributed to the country likely missing its 2020 climate target. Often policymakers did not attempt to develop effective policies or when they did-such as trying to increase the stringency of the emissions trading system - they largely failed, given the opposition from electric utilities and industry.

The outcome of Germany's compensation politics also contrasts with the United States, where - in the absence of compensation-based bargains - coal regions and firms continue to actively resist federal climate policy.

\section{Conclusion}

In this article, we introduced the concept of strategic state capacity to broaden our understanding of state capacity beyond bureaucratic autonomy and to advance recent efforts to reappraise state capacity in advanced industrialized countries (Carpenter \& Moss, 2014; Carpenter, 2001). The discipline's lack of engagement with strategic sources of state capacity has left unexplained why in some cases governments are able to pursue state goals against interest group opposition and not in others, even when bureaucratic capacity does not vary. As we show, state actors across political 
systems in advanced industrialized countries engage in strategic interaction with organized interests, trying to mobilize and de-mobilize interest groups in line with state goals. We identified four generic state strategies toward organized interests - recruiting allies, limiting access, aligning interests, and quieting interests - and discussed a range of tools for policymakers in applying these strategies.

Our argument has implications for debates on interest group intermediation. First, it challenges the idea that pluralist states are mere fora for interest group competition. While the state in pluralist systems is not necessarily engaged in long-term negotiating fora with interest groups as it is in corporatist settings, it nonetheless has an active hand in managing access and preferences of interest groups. The US case on electric vehicle policy and the California case on delegation illustrate this clearly. Second, in systems with higher state-society coordination, the state may not always be tied into rigid institutional structures of long-term interest intermediation. It plays an active role in reproducing and changing these fora, as the case of Germany's coal commission reflects. In the case of France, the government did not seek consensus negotiations, but sided with part of the auto industry in signaling a long-term shift toward electric vehicles.

We suggest four central questions for further research, three of which relate to the sources, choice, and effectiveness of state strategies. First, what explains variation in strategic capacity? As discussed above, individual-level and organization-level factors may account for variation in strategic capacity across political actors and across states. Work on policy entrepreneurs offers a helpful vantage point to examine individual-level characteristics, including learning processes (Baumgartner \& Jones, 1993; Kingdon, 1995). The question of organizational sources of state capacity brings us back to bureaucratic capacity. We want to be clear that bureaucratic autonomy is a necessary but not always a sufficient condition for goal attainment. We assume that bureaucratic and strategic state capacity may be somewhat correlated: a larger professional bureaucracy may harbor the capacity to be strategic toward interest groups. But we also find that there is variation in strategic state capacity among jurisdictions with high bureaucratic capacity. For example, California's successful implementation of its 2020 climate goal discussed above contrasts with Germany's failure to attain its 2020 goal despite similarly competent environmental agencies. Although Germany did not insulate the policy-making process from organized interests, there was no institutional reason that prevented it from doing so (Meckling \& Nahm, 2018b). Several organizational features unrelated to bureaucratic capacity may be important. For example, 
the share of political appointees versus career bureaucrats could affect strategic capacity by shaping knowledge and networks of an organization. Likewise, the reputation of agencies may condition the extent to which they can mobilize interest groups (Carpenter, 2014). Taken together, this suggests that future research into the sources of strategic capacity will help to adjudicate whether strategic capacity tends to co-exist with bureaucratic capacity, or whether it can substitute for it.

Second, if policymakers can choose several strategies to achieve the same goal, what then explains strategy choice? We proposed above that both cost and institutions may matter. For example, quieting interests through compensation may be a very effective but costly strategy. High budgetary expenditures may create trade-offs for policymakers to pursue competing goals. As for institutions, our cases are drawn from pluralist and corporatist political systems to show that strategic state capacity matters in multiple institutional settings. But we do not yet know, for example, how domestic institutions enable or limit certain types of state strategies vis-à-vis interest groups. For example, compensation may be a more likely strategy in democracies that exhibit high levels of coordination between the state and interest groups. Long-term bargaining relations facilitate compensation of policy losers. Also, increased information flows in institutional settings with high degrees of coordination may enhance strategic state capacity. At the same time, limiting access may be less of an option in settings with coordinated or corporatist interest intermediation. Beyond interest group intermediation, legal institutions may condition the scope of usage of strategies. Delegation of policy design to bureaucratic agencies - an important tool to limit access - may face legal constraints. Jurisdictions vary in the extent to which the law permits substantial delegation of authority to bureaucratic agencies (Kischel, 1994). This suggests the need for further research that examines how domestic institutions shape the use of specific strategies over others across countries and institutional contexts.

Third, how effective are different strategies? Answering this question is essential to be able to examine how strategic state capacity is associated with political and policy outcomes. Again, research on social movements offers directions for future research. It points in particular to the features of the strategies themselves and to political opportunity structures as explanatory factors (McAdam et al., 1996). For example, how concentrated versus diffuse and how unified versus divided organized interests may shape the opportunities for policymakers to mobilize or demobilize interest groups (Schurman, 2004). 
Fourth, work on bureaucratic state capacity has raised questions about the normative implications of strong states that also matter for strategic state capacity (Fukuyama, 2013). While such debates have historically focused on autonomous states in corrupt regimes in developing economies, we acknowledge that more state capacity may not be desirable even in advanced economies if bureaucrats and legislators behave in undemocratic and corrupt ways. The strategy of limiting access has the greatest potential to conflict with democratic accountability, though this remains to be explored further. The California case, for instance, suggests that delegation of policy design by the legislature to an autonomous agency limited interest groups' access to legislators, but created a new participatory space through a formal consultation process at CARB. This arguably may have given more equal access to a range of interest groups, independent from their ability to seek access to legislators through campaign finance.

State capacity matters for policy implementation, as the mixed record of the 25 -year battle to implement climate policy in OECD countries reflects. More generally, the question of the state's ability to intervene in the economy is gaining renewed urgency in advanced industrialized countries. Beyond climate change, the rise of China's state-led economy and Western policy responses have begun to re-shape state behavior in rich democracies. Much past scholarship has, however, focused on state capacity in emerging and developing countries. In an era of renewed state intervention, re-appraising the sources of state capacity - both institutional and strategic - in advanced industrialized countries is thus an important endeavor.

\section{Acknowledgments}

We are grateful for feedback from Patrick Bayer, Brian Blankenship, Jared Finnegan, and Federica Genovese. We thank Yan Fan, Nicholas Goedeking, and Daniel Willis for research assistance. This work was supported by the USDA National Institute of Food and Agriculture, Hatch Project Accession Number 1020688. 


\section{References}

Aklin, M., \& Mildenberger, M. (2020). Prisoners of the wrong dilemma: why distributive conflict, not collective action, characterizes the politics of climate change. Global Environmental Politics, 20(4), 4-27.

Aklin, M., \& Urpelainen, J. (2018). Renewables: The Politics of a Global Energy Transition. MIT Press.

Amsden, A. H. (1989). Asia's Next Giant. Oxford University Press.

Andrews, K. T., Baggetta, M., Chaeyoon, L., Marshall, G., Han, H. (2010). Leadership, Membership, and Voice: Civic Associations That Work. American Journal of Sociology 115(4): 11921-1242.

Anzia, S. F., \& Moe, T. M. (2016). Do Politicians Use Policy to Make Politics? The Case of Public-Sector Labor Laws. American Political Science Review, 110(04), 763-777. https://doi.org/10.1017/s0003055416000484

Atkinson, M. M., \& Coleman, W. D. (1989). Strong states and weak states: sectoral policy networks in advanced capitalist economies. British Journal of Political Science, 19(1), 47-67.

Bailey, M. A., Kamoie, B., \& Maltzman, F. (2005). Signals from the tenth justice: The political role of the solicitor general in Supreme Court decision making. American Journal of Political Science, 49(1), 72-85.

Baumgartner, F. R., \& Jones, B. D. (1993). Agendas and Instability in American Politics. University of Chicago Press.

Blondeel, M., \& Van de Graaf, T. (2018). Toward a Global Coal Moratorium? A comparative analysis of coal-mining policies in the U.S., China, India and Australia. Climatic Change.

Bundesregierung. (2018). Einsetzung der Kommission Wachstum, Strukturwandel und Beschäftigung. Retrieved July 18 from https://www.bmwi.de/Redaktion/DE/Downloads/E/einsetzung-der-kommissionwachstum-strukturwandel-beschaeftigung.pdf?_blob=publicationFile \&v=4

Calef, D., \& Goble, R. (2007). The allure of technology: How France and California promoted electric and hybrid vehicles to reduce urban air pollution. Policy sciences, 40(1), 1-34.

California Air Resources Board. (2017). Public comments for draft scoping plan. https://www.arb.ca.gov/cc/scopingplan/spviewdraftcomment.htm 
Campbell, A. L. (2002). Self-Interest, Social Security, and the Distinctive Participation Patterns of Senior Citizens. American Political Science Review, 96(3), 565-574.

Canis, B. (2011). Battery manufacturing for hybrid and electric vehicles: policy issues. .

CARB. (2008). Climate Change Scoping Plan.

Carlson, A. E. (2012). Regulatory Capacity and State Environmental Leadership: California's Climate Policy. Fordham Envtl. L. Rev., 24, 63.

Carpenter, D. (2014). Reputation and power. Princeton University Press.

Carpenter, D., \& Moss, D. A. (Eds.). (2014). Preventing Regulatory Capture. Cambridge University Press.

Carpenter, D. P. (2001). The forging of bureaucratic autonomy: Reputations, networks, and policy innovation in executive agencies, 1862-1928 (Vol. 78). Princeton University Press.

Chrisafis, A., \& Vaughan, A. (2017). France to ban sales of petrol and diesel cars by 2040. The Guardian. https://www.theguardian.com/business/2017/jul/06/france-ban-petrol-dieselcars-2040-emmanuel-macron-volvo

Clear Act Coalition. (2003). Letter to Senator Orrin Hatch.

Colgan, J., Green, J., \& T. Hale (2021). Asset Revaluation and the Existential Politics of Climate Change. International Organization, 1-25. https://doi.org/10.1017/S0020818320000296

Collins, S. (2005). Senator Collins Sponsors Legislation to Encourage Hybrid and Alternative Fueled Vehicles.

Dahl, R. A. (1961). Who Governs? Yale University Press.

Dahlström, C., Lapuente, V., \& Teorell, J. (2012). The merit of meritocratization: Politics, bureaucracy, and the institutional deterrents of corruption. Political Research Quarterly, 65(3), 656-668.

Dalmia, S., \& Payne, H. (2009). Cross country: Detroit bets its future on Washington. Wall Street Journal, Section A; Column 1.

Department of Energy. (2006). Partnership Plan: FreedomCAR and Fuel Partnership.

Dixit, A. (2002). Incentives and organizations in the public sector: An interpretative review. Journal of human resources, 37(4), 696-727. 
Dryzek, J. S., Hunold, C., Schlosberg, D., Downes, D., \& Hernes, H.-K. (2002). Environmental transformation of the state: the USA, Norway, Germany and the UK. Political Studies, 50(4), 659-682.

Evans, P. (1995). Embedded Autonomy. Princeton University Press.

Evans, P. (1997). The Eclipse of the State? Reflections on Stateness in an Era of Globalization. World Politics, 50(1), 62-87. https://doi.org/10.1017/S0043887100014726

Finnegan, J., Lipscy, P., Meckling, J., \& Metz, F. (2021). The Institutional Sources of Economic Transformation: Energy Policy from the Oil Crises to Climate Policy. APSA Preprints.

Fukuyama, F. (2013). What Is Governance? Governance, 26(3), 347-368. https://doi.org/10.1111/gove.12035

Ganz, M. (2000a). Resources and Resourcefulness: Strategic Capacity in the Unionization of California, Agriculture, 1959*1966. American Journal of Sociology, 105(4), 1003-1062.

Ganz, M. (2000b). Resources and Resourcefulness: Strategic Capacity inthe Unionization of California Agriculture, 1959-1966. American Journal of Sociology, 105(4), 1003-1062.

Ganz, M. (2009). Why David Sometimes Wins. Oxford University Press.

Gilens, M., \& Page, B. I. (2014). Testing Theories of American Politics: Elites, Interest Groups, and Average Citizens. Perspectives on Politics, 12(03), 564-581. https://doi.org/10.1017/s1537592714001595

Groupe PSA, 2019. Electrification in Motion. https://www.groupe-psa.com/en/automotivegroup/innovation/groupe-psa-lelectrification-en-marche/ [Accessed December 12, 2020].

Hall, P. A., \& Soskice, D. (2001). An Introduction to Varieties of Capitalism. In P. A. Hall \& D. Soskice (Eds.), Varieties of Capitalism: The Institutional Foundations of Comparative Advantage. Oxford University Press.

Handelsblatt. (2019). So bewerten die Betroffenen den Ausstiegsplan der Kohlekommission." Handelblatt. Retrieved July 18 from https://www.handelsblatt.com/politik/deutschland/kohleausstiegso...ission/23914186.html?ticket=ST-10355228-wehkqVswV0ZsVBb5MtZ2-ap3

Hatch, M. T. (1995). The politics of global warming in Germany. Environmental Politics, 4(3), 415-440. 
Held, A. (2017). France Plans To Ban Sale Of Diesel And Gas Vehicles By 2040. National Public Radio. https://www.npr.org/sections/thetwo-way/2017/07/06/535799765/franceplans-to-ban-sale-of-diesel-and-gas-vehicles-by-2040

Hertel-Fernandez, A. (2018). Policy Feedback as Political Weapon: Conservative Advocacy and the Demobilization of the Public Sector Labor Movement. Perspectives on Politics, 16(2), 364-379. https://doi.org/10.1017/s1537592717004236

Hochstetler, K., \& Kostka, G. (2015). Wind and solar power in Brazil and China: interests, statebusiness relations, and policy outcomes. Global Environmental Politics, 15(3), 74-94.

Horowitz, M. C., Poast, P., \& Stam, A. C. (2017). Domestic signaling of commitment credibility: Military recruitment and alliance formation. Journal of Conflict Resolution, 61(8), 16821710.

Howell, C., \& Givan, R. K. (2011). Rethinking institutions and institutional change in European industrial relations. British Journal of Industrial Relations, 49(2), 231-255.

Huber, J. D., \& Shipan, C. R. (2002). Deliberate discretion?: The institutional foundations of bureaucratic autonomy. Cambridge University Press.

Hultman, M., \& Nordlund, C. (2013). Energizing technology: expectations of fuel cells and the hydrogen economy, 1990-2005. History and Technology, 29(1), 33-53.

Immergut, E. M. (1998). The theoretical core of the new institutionalism. Politics \& Society, 26(1), 5-34.

IPCC. (2018). Global Warming of $1.5^{\circ} \mathrm{C}$.

Jasanoff, S. $(1985,1985 / 02 / 01)$. Technological innovation in a corporatist state: The case of biotechnology in the Federal Republic of Germany. Research Policy, 14(1), 23-38. https://doi.org/http://dx.doi.org/10.1016/0048-7333(85)90022-8

Karapin, R. (2016). Political Opportunities for Climate Policy. Cambridge University Press.

King, D., \& Lieberman, R. C. (2009). Ironies of State Building: A Comparative Perspective on the American State. World Politics, 61(3), 547-588. https://doi.org/10.1017/S0043887109000185

Kingdon, J. (1995). Agenda, Alternatives, and Public Policies. Longman.

Kischel, U. (1994). Delegation of Legislative Power to Agencies: A Comparative Analysis of United States and German Law. Admin. L. Rev., 46, 213. 
Kitschelt, H., Lange, P., Marks, G., \& Stephens, J. D. (1999). Convergence and Divergence in Advanced Capitalist Democracies. In G. Marks, H. Kitschelt, J. D. Stephens, \& P. Lange (Eds.), Continuity and Change in Contemporary Capitalism (pp. 427-460). Cambridge University Press. https://doi.org/DOI: 10.1017/CBO9781139175050.017

Krasner, S. D. (1978). United States Commercial and Monetary Policy: Unravelling the Paradox of External Strength and Internal Weakness. In P. J. Katzenstein (Ed.), Between Power and Plenty (pp. 51-87). University of Wisconsin Press.

Le Galès, P., \& King, D. (2017). Introduction: A Reconfigured State? European Policy States in a Globalizing World. In Reconfiguring European States in Crisis. Oxford University Press. https://doi.org/10.1093/acprof:oso/9780198793373.003.0001

Lundqvist, L. (1980). The tortoise and the hare: Clean air policies in the United States and Sweden. Ann Arbor, MI: University of Michigan Press.

Martin, C. J., \& Swank, D. (2012). The political construction of business interests. Cambridge University Press.

McAdam, D., McCarthy, J., \& Zald, M. N. (Eds.). (1996). Comparative Perspectives on Social Movements. Cambridge University Press.

Meckling, J., \& Nahm, J. (2018a). When do states disrupt industries? Electric cars in Germany and the United States. Review of international Political Economy.

Meckling, J., \& Nahm, J. (2018b). The power of process: State capacity and climate policy. Governance. https://doi.org/10.1111/gove.12338

Meckling, J., \& Nahm, J. (2019). The politics of technology bans: Industrial policy competition and green goals for the auto industry. Energy Policy. 126: 470-479.

Meckling, J. \& Trachtman, S. (2021). The home state effect on national business coalitions: Evidence from U.S. climate politics. APSA Preprints: doi: 10.33774/apsa-2021-bn5gp.

Meyer - Sahling, J. H., \& Mikkelsen, K. S. (2016). Civil service laws, merit, politicization, and corruption: The perspective of public officials from five East European countries. Public administration, 94(4), 1105-1123.

Ministry for the Ecological and Inclusive Transition. (2017). Climate Plan.

http://www.gouvernement.fr/en/climate-plan 
Nistotskaya, M., \& Cingolani, L. (2015). Bureaucratic structure, regulatory quality, and entrepreneurship in a comparative perspective: Cross-sectional and panel data evidence. Journal of Public Administration Research and Theory, 26(3), 519-534.

Noble, B. (2020). Future Stellantis CEO says PSA is not investing in internal combustion engines. The Detroit News, November 16.

Paster, T. (2013). Business and Welfare State Development: Why Did Employers Accept Social Reforms? World Politics, 65(3), 416-451. https://doi.org/10.1017/S0043887113000117

Potoski, M., \& Woods, N. D. (2002). Dimensions of State Environmental Policies: Air Pollution Regulation in the United States. Policy Studies Journal, 30(2), 208-226.

Renn, O., \& Marshall, J. P. (2016). Coal, nuclear and renewable energy policies in Germany: From the 1950 s to the "Energiewende". Energy Policy. https://doi.org/10.1016/j.enpol.2016.05.004

Reuters. (2019). France to uphold ban on sale of fossil fuel cars by 2040. Retrieved November 11 from https:/www.reuters.com/article/us-france-autos/france-to-uphold-ban-on-saleof-fossil-fuel-cars-by-2040-idUSKCN1TC1CU

Rothstein, B. O., \& Teorell, J. A. (2008). What is quality of government? A theory of impartial government institutions. Governance, 21(2), 165-190.

Samuels, R. J. (1987). The Business of the Japanese State. Cornell University Press.

Schmitter, P. C. (1977). Modes of interest intermediation and models of societal change in Western Europe. Comparative Political Studies, 10(1), 7-38.

Schurman, R. (2004). Fighting 'Frankenfoods'. Industry Opportunity Structures and the Efficacy of the Anti-Biotech Movement in Western Europe. Social Problems 51(2), 243-268.

Schwarz, S. (2019, April 4). Geldsegen für die Kohleländer. Klimareporter. https://www.klimareporter.de/deutschland/geldsegen-fuer-die-kohlelaender

Skocpol, T. (1980). Political response to capitalist crisis: Neo-Marxist theories of the state and the case of the New Deal. Politics \& Society, 10(2), 155-201.

Skocpol, T. (1985). Bringing the State Back In: Strategies of Analysis in Current Research. In D. Rueschemeyer, P. B. Evans, \& T. Skocpol (Eds.), Bringing the State Back In (pp. 3-38). Cambridge University Press

Skocpol, T., \& Finegold, K. (1982). State Capacity and Economic Intervention in the Early New Deal. Political Science Quarterly, 97(2), 255-278. 
State of California. (2006). Assembly Bill No. 32. Sacramento: State of California. .

Steinmo, S. (2010). The Evolution of Modern States. Cambridge University Press. https://doi.org/DOI: 10.1017/CBO9780511762185

Stokes, L. C. (2020). Short circuiting policy: Interest groups and the battle over clean energy and climate policy in the American States. Oxford University Press.

Streeck, W. (2016). Von Konflikt ohne Partnerschaft zu Partnerschaft ohne Konflikt: Industrielle Beziehungen in Deutschland. Industrielle Beziehungen, 23(1), 47-60.

Swenson, P. A. (2018). Misrepresented Interests: Business, Medicare, and the Making of the American Health Care State. Studies in American Political Development, 32(1), 1-23. https://doi.org/10.1017/s0898588x18000019

Taylor, D. (2009). Current federal authorized programs on plug-in hybrids, battery electric vehicles, and related efforts. In D. Sandalow (Ed.), Plug-in electric vehicles: What role for washington? Brookings Institutions Press.

Thelen, K. (2014). Varieties of liberalization and the new politics of social solidarity. Cambridge University Press.

Tietge, U., Mock, P., Lutsey, N., \& Campestrini, A. (2016). Comparison of Leading Electric Vehicle Policy and Deployment in Europe.

Trachtman, S. (2021). Policy Feedback and Interdependence in American Federalism: Evidence from Rooftop Solar Politics. Perspectives on Politics.

UNFCCC. (2019). UN Climate Change Annual Report 2018.

United Nations. (2018). UN Comtrade Database. https://comtrade.un.org/data/

Uriu, R. M. (1996). Troubled Industries: Confronting Economic Change in Japan. Cornell University Press.

Vogel, D. (2012). The politics of precaution. Princeton University Press.

Wade, R. (1990). Governing the Market - Economic Theory and the Role of Government in East Asian Industrialization. Princeton University Press.

Weber, M. (1978). Economy and Society. University of California Press.

Weir, M. and Skocpol, T. (1985). "Keynesian" Responses to the Great Depression. In P. B. Evans, \& T. Skocpol (Eds.), Bringing the State Back In (pp. 3-38). Cambridge University Press. 
Weiss, J. C. (2013). Authoritarian signaling, mass audiences, and nationalist protest in China. International Organization, 67(1), 1-35.

Wolford, S. (2014). Showing restraint, signaling resolve: Coalitions, cooperation, and crisis bargaining. American Journal of Political Science, 58(1), 144-156.

Woll, C. (2008). Firm interests: How governments shape business lobbying on global trade. Cornell University Press. 